\title{
The Intention and Practices of Charity by Females
}

\author{
Komal Niazi *1, Dr. Waheed Chaudhary ${ }^{2}$, Dr. He Guoqiang ${ }^{3}$ \\ ${ }^{1}$ Ph.D. Candidate of Anthropology, School of Sociology and Anthropology, Sun Yat-sen University, \\ Guangzhou, China ${ }^{2}$ Associate Professor, Department of Anthropology, \\ Quaid-i-Azam University, Islamabad, Pakistan \\ ${ }^{3}$ Professor, Department of Anthropology, School of Sociology and Anthropology, Guangzhou, china
}

\begin{abstract}
The paper focused on "The Intention and practices of Charity by females". Charity is defined as giving to those in need, or love of one's fellow men. This paper literature states that women are more interested to donate charity and men are more interested in given money in charitable acts. The study deals with the different cultural norms and values that directly affect the behaviour, attitude, practices, intentions and beliefs regarding female charity practices. The study also highlights the various socio-economic and cultural patterns that shape and define female charity practices and intentions in all age of women. Anthropological research data was used to collect the data. The researcher also used the snowball sampling technique to get required information from the target population. Snowball sampling is non-probability sampling technique where researcher gets referrals from respondent about other respective respondents to acquire desired information. Case studied taken in the field proved to be very useful for collecting the original information. Main findings of study clearly ascertained that research was to find out the conceptual understanding of female about various kinds of charity, evaluation of social value by enumerating the kinds and types of charity by the female and to study the stimulants of female's charities. Females are more generous in terms of Charity rather than men.
\end{abstract}

Keywords: Female Charity, Charity Intentions, Practices and Cultural norms

\section{Introduction}

Charity is defined as giving to those in need, or love of one's fellow men. Charity both obligatory almsgiving and voluntary donations was and is an established practice for Muslims throughout the world. The concept of charity goes back to ancient era, and the practice of contribution for the poor has roots in all religions of world. The word charity comes from the Latin word caritas, which means love. All the key religions of the world focus to contribute for those in need e.g. for Christians, "Charity Never Filth". Buddhists assumed that kindness is a basic component of life. Muslims practice helpful giving as one of the five pillars of their religion. Charities and volunteering are supposed to be the greatest examples of "love in action." Many people believe that they receive a lot in some other way by giving (Belaon, 2014). The concept of charity derives from the fact to acknowledge that we own nothing but whatever has been given to us is a blessing from Allah (SWT) and it's His property. So, when we give out something from our pocket, we are sharing Allah's blessings with His mankind and since we don't own anything, we don't lose anything by giving out but only gain Allah's rewards (Piliavin, 2003). Charity is an extension of love into action, ranges from traditional alms-giving to forms of generosity. It takes over actually, determining a full day's work for a full day's pay involves a great deal (Mckee, 1992). Different people practice charity for different purposes. Most the people donate and practice charity to be blessed by God. Poor or miserable condition of the people motivates them to donate something in the way of Allah (Kahneman, Krueger, Schkade, Schwarz, \& Stone, 2006). They contribute something to fulfil basic needs of the poor. Moreover, people also donate charity because they believe that donating some portion of their wealth in the name of Allah can reduce their miseries and at the same time their wealth and assets would remain pure (larry, 2008). Similarly, people also believe that through the practice of charity they can gain respect and status in society and this thing can be helpful in gaining a political power in the community. We can evaluate charity in economic, social, cultural and religious perspectives. Among these perspectives, the religious perspective is the most effective in all the societies (Andreoni, 2007). Almost all the religions support charity and motivate their followers to adopt that, taking the case of Islam, it gives a great concern on the importance of 
charity, which is clearer in these verses of Quran "Let those who give alms, both men and women, and lend unto Allah goodly loan, it will be doubled for them and their will be a rich reward" (Quran, 2000). Adult females are more generous than men. Only the adult females do not give charity in money (Mary A. O'Herlihy, Havens, \& Schervish, 2002). Siegel talked about earlier, females visiting the poor cottages frequently because in that setting she can be superficial and in a sense untouchable, whereas if she is charitable within her own dwelling and with her own servants, they might take liberties (Siegel, 2012). Female enclosure is a prominent theme in discussions of girls and women in early modern areas of Charity (Jeronimo, 2003). Recent studies have begun to demonstrate that prescriptive statements and commentary do not capture the full range of early modern Spanish women's activities and movement (Nader, 2004).Themes of female enclosure are not unique to unmarried girls or married women (Bremen, 2012). Institutions existed for women whose virtue was endangered by the absence of adequate family protection, as orphans, daughters of poor or indecorous parents, wives of vicious husbands, abandoned spouses or widows; indocile girls and wives could be enclosed against their will by relatives (Carman, 2004). Victims of seduction could redeem themselves or at least give birth in decent secrecy, poor virtuous, physically attractive girls could earn their dowry by spending seven years in an institution (Cohen, 1992). Individual women of all classes participated in traditional form so f personal giving, such as distributing alms and caring for the sick poor, that endured into the twentieth century (Khan, 2013). At the same time, private charitable organizations, which numbered several thousand by 1900, relied heavily on money, time, and effort donated by women (Karlan\&List, 2004). Women who sought to participate in public life inn, like most of their Western counter parts, had to contend with cultural norms that confined them to the home and family (Cotterill, John, \& Richardson, 2010).

\section{Objectives}

Women may likewise be distinguished by their eagerness to both give and volunteer at more elevated amounts than their male partners. Ladies, by and large, give twice as much to philanthropy and make three times the quantity as compared men. The main aim of the study was how women intentions and practices are involved in charity. So, hence, following objectives were set.

- To investigate the socio-cultural stimulants for charity amongst women.

- To investigate the cultural norms and values that directly relates to intentions and beliefs regarding female charity practices.

\section{Methodology}

Anthropologists built up a portion of the generally utilized strategies for discovering designs in content, for concentrate how individuals utilize their chance, and for figuring out how individuals decide. Those techniques are up for snatches by everybody. The Methodology involves the selection of techniques and methods used for the collection of data. This includes the assumptions and values that serve as a rationale for the research and the standards or criteria the researcher uses in interpreting data and reaching conclusions. This research was based on anthropological study and there was a need of specific methodology that helps in ladder of abstraction to produce and organized the relevant data. Informal interviews, participant observation, case studies were used as tools to get the relevant data from the field. Snowball sampling is non-probability sampling technique where researcher gets referrals from respondent about other respective respondents to acquire desired information. Specifically, the researcher selected snow-ball sampling technique for this respective research because it is not possible to include or insured the participation of all the natives of that respective locale for this study because the nature of study demands those natives who were involved in the practice of charity. Participant Observation was applied by the researcher for her research initiatives and in-depth knowledge about people and locale and to collect the quantitative as well as qualitative data of descriptive nature and to remove the barriers confronted in the community. The researcher was an active, but a passive member of the community. The researcher participated in all events of social importance during my stay at the locale. Case studies improve the quality of 
data in a great deal. The researcher also collected data through case studies because it provided a ground to get first-hand data from the natives about knowledge of charity practices in detail with accordance to the socioeconomic characteristics of respective respondents.

\section{Charity Intentions and Practices}

Charity is a method of donating money, food and services to those who are in need, facing miserable circumstances, having not enough resources to meet their basic or daily life requirements. (Mary A. O'Herlihy, Havens, \& Schervish, 2002). Muslim beliefs have inspired charitable giving for over fourteen centuries, yet Islamic history has rarely been examined from this perspective. A standout amongst the most essential lessons from the behavioral science writing is that on the off chance that you need to energize somebody to accomplish something, you should make it as simple as feasible for them to do as such (Charities-and-Foundation, 2010). Females have done charity, because this act has also given then happiness along with the satisfaction so, Din Akon and Nortan said, Incidentally, the potential for cash to build satisfaction might be subverted by the sorts of decisions that reasoning about cash advances; the simple idea of having cash makes individuals less inclined to enable associates, to give charity (Dunn, Aknin, \& Nortan, 2008). Females are very important part of the society and they also play an important role to construct a society. When we talk about the charitable practices and their indigenous knowledge, females play a vital role in these practices. Normally charity begins at home, when we were small children our parents, especially our mother told the way of methods to help the poor and needy person. Over the past decades, Charity was done by females rather than male. Female's charities consist of kinds rather than money. So, found a comparative relationship between pay, ways of managing money, and subjective well - being in the all-inclusive community. The more individuals spent on giving, paying little respect to their genuine pay, the higher their well - being (Halprin, 2010). Our Indigenous knowledge of the traditions, norms and values which are practiced in our houses, are reshaping our charitable practices in the society. So, Sanders Norton and Smith defined that Charities themselves may likewise offer motivating forces of the shape, where one individual's gift is coordinated by cash from another source (Sanders, Smith, \& Norton, 2013). So, it means how we practice in these activities. How much giving helps the people and how we give? Why society consider female donate more than men? Why male donates money than female? These all things we learned from our houses at the beginning of the learning stages. So, Vesterlund presents a hypothetical model in which persons who are ignorant of the charitable quality of giving to move in succession. In this model, the people who moves initially takes part in an exorbitant hunt to decide the charitable quality of giving (Vesterland, 2003). So, Potters et al. also supports that argument, a comparative theory tentatively, finding that educated operators are endogenously moved to start with, and that consequent charitable activities arrange on their gifts (Potters, Sefton, $\&$ VesterLund, 2005). In these entire scenarios, a female played a vital role. Female Charitable practices to serve or support at a small level in different categories. Many Studies analyze that charitable practices combined with the religious congregation. Thus, it is hardly surprising that a relationship is found in people's religiosity and giving is interrelated with each other.

\section{Indigenous Knowledge}

As for as the question of local understanding about the charity is concerned, we clearly come to know that the Indigenous knowledge about the charity points to different social, religious and demographic features of the charity. Indigenous knowledge always depends on previous experiences and socially embedded features (Women-Philintherophy-Institute, 2015). Residential adaptations, religious following and traditional learning are the major field of concerns regarding women charitable behaviors (Women-Philonthropy-Institute, 2014). Charity is not only a part of religion only; it also inherits our cultural roots. Some people who are not religious are also involved in charitable practices (Mill, 2010). They give charity to start any work, to get success, through these charities Allah will bless them and give them more in this way. During research, the respondents clearly claimed that these practices are always practiced in their houses, so each person of the society is totally familiar and 
satisfied with it. These practices are inherited from generation to generation. The traditional charitable practices are also linked with religion however. No doubt religion keeps primary stack for justified performance of these charitable practices at large scale. Fourth percent of respondent told me many hadiths are linked with the charity. Fifty percent of women said that who give more in the way of Allah, Allah will give more. Religiosity is defined as a relationship with a religious tradition and the rate of attendance at religious services (Millward, Richard, Rael, \& Sinha, 2015). Respondents were asked how often they attend religious services: every week, once or twice a month, a few times a year, hardly ever, or never. Thirty percent of the sample was not affiliated with a religious tradition. These are people who say they are not much religious, or nothing. Respondents who are not involved in religious activities also perform charitable practices, their traditional knowledge and practices taught them to involve in charitable practices to help poor and give them their basic needs. These people are the only a way to give them, because Allah give them a lot of money and resources, so rich people should help poor and needy, because charity is a way to get the blessings of Allah, to help the poor and needy people. Seventy percent of respondents told the routine of performance of the charitable practices which are daily like a small amount of money to beggars as a sadka (Sadka is a part of voluntary charity. It is given when people have seen bad oms in their dreams. So, they distributed among people as a form of money or raw meat) and khairat (It is also part of the voluntary charity. It was distributed among people even on daily routine. Khairat was most of time was given in the form of cooked food weekly like give the food items or cooked food as a khairat or throw raw meat on the roof for birds as a Sadka, monthly like a goat was sacrificed on the name of Allah and its meat sent to the Madrassa's children as a sadka and many of them were associated to special occasions like Shab-e-Barat, Eid Miladun Nabi, Giarwi Sharif, Shabe Kadar, On the birth of child, on marriage ceremony etc. The people always followed their elders at home who performed charitable acts in their lives. Twenty percent house wives which were not empowered, even though they always preferred to help poor from their small pocket money and daily expenditures were given by their husbands. In fact, twenty percent of the women had a limited access to money, but they performed their charitable practices through kinds like vegetables, flour, sugar, milk etc.

\section{Motivations that Involved in Charity}

The motivating factors encourage charitable practices. Motivations are important factors that impacts female lead and to become givers in the first place. The motivations of the charitable giving by the wealthy more succinctly is the major motives of the donors (U.S.A.Trust, 2013). Motivations of charitable practices of giving are both simple and complex (Morrison \& Sabarwal, 2008). The simple part is that what motivates the wealthy very much and what motivates someone at any point along the economic spectrum (United-Nation-Development-prograamme, 2010). The complex part about the charitable motivation of the wealthy is that those who hold great wealth and consciously direct it to social purposes invariably wanting to shape rather than merely support a charitable cause (Nicholas \& WuDunn, 2009). Twenty-three percent of respondents have had different views about the motivations of charity. Females have had the view that Islamic values motivate to help poor. They narrate the charity as a way by which money rotate in the society and poor are benefited from it. They believe that if they do not participate in charitable practices, the God will get angry with them. It is the religious responsibility to help the poor and needy person. Allah says who help others I will help them. So, to get reward from Allah, people help the poor and needy. Religion is a best motivational factor that persuades the people to involve in charitable practices. Twenty percent of respondents expressed that this is the moral and social responsibility to help others through charitable practices. All the people was living in an area were not rich. Some people could not enjoy even their basic needs. So, a neighbor should help through money and different kind of things. It is the part of humanity to help one who is in miserable condition. People whom they do not help the poor especially their relatives and neighbors, 
they could not lie in the category of humans. Keeping in view one's bad living conditions, so it is our moral and social responsibility to help them through charitable practices. Fifty seven percent of the respondents also have had the view "one who have faced poverty in his past or even in his childhood, he could not see another in the same condition".

\section{Level of Satisfaction}

No research has been conducted to study the male to female differences regarding religiosity giving relationship (Girl-Effect-Organization, 2006). However, a general belief has been developed which possess a reflection of the philosophy that women contribute more than men. Among the theories are men and women are socialized into gender specific roles where women's traditional family role is a caregiver, nurturer, and mother (LutheranWorldFederation, 2002). As major socializers of their children, mothers model religious behavior such as affiliation and attendance to set examples for their children. Women have more time to devote to religion because of the gender-based division of labor within the home (Bell, 2005). Working less outside the home provides women with more time to pursue religious-related activities. Women are more religious because of their hatred to the risk associated with binger religious (LWF-Women-Magzine, 2016). Some have argued that a risk-averse person will deal with uncertainties such as weather, disease and even death in culturally appropriate ways such as participating in religion. (Mesch, Ottoni-Wilhelm, Osili, Hayat, \& Pactor, 2014). The satisfaction is an extremely personal and psychological state which varies from person to person as well as society to society (Clark, 2005). Whenever one help others, it creates an improved sense of well-being. When one sacrifice something such as time, well, finances or property to help poor in need can give a realistic sense of purposive life and moral satisfaction. While numerous requests for Charity focus on the idea that helping (Eriksson, 1995). The research proved that cheerful individuals give more, that giving relates to and liking giving causes satisfaction, and that these connections may keep running in a round manner, such that glad individuals give more, then feel more satisfied, then give more, etc. When individuals begin to give for childish reasons keeping in mind the end goal to feel great rather than un-selfish reasons, to help other people, such extraneous inspirations may swarm out characteristic inspiration to help. Seventeen percent of respondents have had the view after giving charity to poor and needy people, they have achieved inner satisfaction. People has accessed their needs because of them. Females have performed charity in different ways. Females were financially independent help others through money, so their satisfaction level was different from the house wives. Twenty two percent of females have given money for a student's education, they have got maximum satisfaction because this charity has built a future of the student. These students would become a future of the country as well as a supporting hand of their parents. The students would also to contribute the

economy of the country. Seventeen percent of the female respondents who have given charity in kinds had a different level of satisfaction. They often used to donate commodities to those people who have not enough money to purchase their basic needs.

\section{Conclusion}

The purpose of the research was to find out the conceptual understanding of female about various kinds of charity, evaluation of social value by enumerating the kinds and types of charity by the female and to study the stimulants of women's charities. The research concluded that women of the society completely realize the importance of various kinds of charity and perform them per environment and importance of the occasion and its social requirement. The women of the locale during research give a clear concept of social understandings about the charity. The charity giver women explained their inspirations for charity giving process. Keeping in view the hypothesis of the research we come to know about a fundamental factor which drives the whole process of charity. The religion is basic inspiration of the givers to give. The receivers cannot ignore the religious inspiration as primary 
stimulant for the givers to proceed in positive way. Almost all the women in the locale keep the importance of the religious teaching regarding charity giving more sacred and precious. The primer inspiration will always be the religious teaching. However, $t$ our hypothesis is not fully supported by the research, insecurity and vulnerability does not directly affect the positive or negative proceedings regarding charity. The hypothesis can occasionally be evaluated but it might be applicable in any individual case but overall, this is wrong.

\section{References}

[1] Andreoni, J. (2007). San Diego Charitable Giving New Palgrave Dictionary of Economics. University of Califoronia. America: Palgrave Dictionarry.

[2] Belaon, A. (2014). Muslim Charities: A Suspect sector. Journal of Anthropology America, 6th , 101-110.

[3] Bell, H. (2005). Te Will to Change: Men, Masculinity, and Love (New York: Washington Square Press, 2005). New York: Washington Square Press.

[4] Bremen. (2012). Give Morre Tomarrow. Journal of public Economics, 223-228.

[5] Carman. (2004). Social Influences and the Designation of Charitable Contributions: Evidence from the Work Place. Islamic and Religious Studies.

[6] CharitiesandFoundation. (2010). Applying Behavrioul insights to Charitable giving. London: Cabienet Office Behavrioul Insight team.

[7] Clark, C. M. (2005). Relations Between Social Support and Physical Health. Rochester Institute of Technology. New york: SAPA Project Test.

[8] Cohen, S. (1992). The Evolution of Women's Asylums since 1500: From Refuges for Ex-Prostitutes to Shelters for Battered Women. New York: Oxford Univ. Press.

[9] Cotterill, John, R., \& Richardson, J. (2010). The impact of a pledge campaign and the promise of publicity on charitable giving: a randomised controlled trial of a book donation campaign. Randomised controlled trials in the Social science Conference (pp. 210-230). Nwe York: Randomised controlled trials in the Social science Conference.

[10] Dunn, E. W., Aknin, B. L., \& Nortan, I. M. (2008). Spending Money on Others Promotes Happiness. USA: University Britishof colombia and Harvard School of Busineess.

[11] Eriksson, A.-L. (1995). Meaning of Gender in Teology: Problems and Possibilities. Uppsala: Acta Universitatis Upsaliensis, Uppsala Women's Studies, Women in Religion, 225-250.

[12] GirlEffectOrganization. (2006). Creating a Women's Fund Within a Community Foundation: A Philanthropic Strategy for Women and Girls. Bermin: Chambers Family fund.

[13] Halprin, D. (2010). Giving, well-being, and behavioural science. UK: Institute of Government.

[14] Ignacio, J., \& Garcia, C. (1993). The chronic poverty of these institutions in the sixteenth and seventeenth centuries (3 ed.). Seville: Ayuntamiento de Sevilla.

[15] Jeronimo, M. d. (2003). Translated and excerpted in Early Modern Spain: A Documentary History. Documentry history, 15, 141-142.

[16] Kahneman, D., Krueger, A. B., Schkade, D., Schwarz, N., \& Stone, A. A. (2006). Charity practices. America: Social Reserch Institure.

[17] Karlan\&List. (2004). Does price matter in charitable giving? Evidence from a large scale natural field Experiment. American Economic Review, 1774-1793.

[18] Khan, A. (2013). Remember a Charity: Why are gifts so Important to charity. UK: Chrity Organization.

[19] larry, S. (2008). How to raise planned gifts by Mall. London: Emerson and Church publication.

[20] Lindenmeyr, A. (1993). Public Life, Private Virtues: Women in Russian Charity, 1762-1914. University of Chicago Press, 8(3), 562-591. 
https://doi.org/10.1086/494820

[21] LutheranWorldFederation. (2002). A Faith reflection on Gender and power. Department for Mission and Development Women in church and Society. London: The Lutheran World Federation.

[22] LWF, W. M. (2016). Concept of Gender: A Just Analytical Tool,. Geneva: LWF Women magazine.

[23] Mary A. O'Herlihy, Havens, J. J., \& Schervish, P. G. (2002). Charitable Giving: How Much, By Whom, To What, and How? Chestnut Hill: Tale Press.

[24] Mckee, A. (1992). "On Justice and Charity" _ A Comment. Taylor \& Francis, Ltd, Vol 50(53), 333-335. https://doi.org/10.1080/758537077

[25] Mill, J. S. (2010). The Subjection of women. American Journal, 288-310. https://doi.org/10.1002/9781118011690.ch22

[26] Millward, J., Richard, N. S., Rael, P., \& Sinha, M. (2015). Finding Charity Folk:Enslaved and free Black women in Maryland. USA: University of Georgia Press.

[27] Morrison, A., \& Sabarwal, S. (2008). The Economic Participation of Adolescent Girls and Young Women: Why Does It Matter? New York: The World Bank.

[28] Nader, H. (2004). Introduction: The World of the Mendozas," in Power and Gender in Renaissance Spain: Eight Women of the Mendoza Family, 1450-1650. Helen Nader, 20(6), 1-26.

[29] Nicholas, D. K., \& WuDunn, S. (2009). Half the Sky: Turning Oppression into Opportunity for Women Worldwide. italy: Vintage Books.

[30] Piliavin, J. A. (2003). Flourishing: Positive psychology and the life well-lived. Social sciences, 227-247.

[31] Potters, J., Sefton, M., \& VesterLund, L. (2005). After you endogenous sequencing in voluntary contribution games. Journal of Public Economics, 89(8), 1399-1499.

https://doi.org/10.1016/j.jpubeco.2004.02.008

[32] Quran. (2000). Versus About Charity. In Holy book (p. 18). Arab: Holy book Publishers.

[33] Sanders, M., Smith, S., \& Norton, M. I. (2013). Non-Standard Matches and Charitable giving. UK, London: Harvard Business School Working Paper.

[34] Schervish, P. G. (1997). Inclination, Obligation and assciation: What we know and what we need to learn about donor Motivation. San Francisco: Jossey Bass: Critical Issues in Fund Raising.

[35] Siegel, D. (2012). Charity and Condescension: Victorian Litreture and the Dillemas of Philathrophy. Ohio University Press, 4.

https://doi.org/10.1353/book.13711

[36] U.S.A.Trust. (2013). High Impact Giving to Women and Girls. New York: A Guide for Donors Philanthropic Solutions.

[37] United-Nation-Development-prograamme. (2010). Women's Empowerment Principles,United Nation development Fund for Women. USA: United Nation.

[38] Vesterland, L. (2003). The Information value of Sequentiol Fund Raising. Journal of Public Economics, 87(3), 627657.

https://doi.org/10.1016/S0047-2727(01)00187-6

[39] Women-Philintherophy-Institute. (2015). The impact of Generation ad Gender on Philanthrophy. United States: Fidelity Charitable.

[40] Women-Philonthropy-Institute. (2014). Fidelity Investments, “Money Fit Women, ”. USA: Fidelity Institute. 